\title{
Evidence on measures for the prevention of ventilator-associated pneumonia
}

\author{
L. Lorente*, S. Blot ${ }^{\#}$ and J. Rello ${ }^{\top,+}$
}

ABSTRACT: Ventilator-associated pneumonia (VAP) continues to be an important cause of morbidity and mortality in ventilated patients.

Evidence-based guidelines have been issued since 2001 by the European Task Force on ventilator-associated pneumonia, the Centers for Disease Control and Prevention, the Canadian Critical Care Society, and also by the American Thoracic Society and Infectious Diseases Society of America, which have produced a joint set of recommendations.

The present review article is based on a comparison of these guidelines, together with an update of further publications in the literature. The 100,000 Lives campaign, endorsed by leading US agencies and societies, states that all ventilated patients should receive a ventilator bundle to reduce the incidence of VAP.

The present review article is useful for identifying evidence-based processes that can be modified to improve patients' safety.

\section{KEYWORDS: Ventilator-associated pneumonia}

V entilator-associated pneumonia (VAP) continues to be an important cause of morbidity and mortality in critically ill patients [1-3]. The present review article is based on a summary of the evidence from the literature and the guidelines for the prevention of VAP produced by the European Task Force (ETF) in 2001 [4], the Centers for Disease Control and Prevention (CDC) in 2004 [5], the Canadian Critical Care Society (CCCS) in 2004 [6] and the American Thoracic Society and Infectious Diseases Society of America (ATS-IDSA) in 2005 [7], focusing on the measures described in these guidelines. The measures to prevent VAP can be classified as pharmacological (table 1) and nonpharmacological (table 2).

\section{SEARCH STRATEGY}

Medline searches of publications in English from 1966 to 2006 were carried out for the following major topic headings: "ventilator-associated pneumonia", "orotracheal intubation", "nasotracheal intubation", "endotracheal tube cuff pressure", "aspiration of subglottic secretions", "extubation", "re-intubation", "noninvasive ventilation", "tracheostomy", "respiratory filters", "change of breathing circuits", "heat and moisture exchanger", "heated humidifier", "closed tracheal suctioning system", "open tracheal suctioning system", "change of closed tracheal suctioning system", "sterilization", "disinfection", "barrier measures", "kinetic bed", "semirecumbent position", "supine position", "gastric feeding", "post-pyloric feeding", "selective digestive decontamination", "preventive intravenous antibiotics", "chlorhexidine oral rinse", "ranitidine", "sucralfate", "sedation", and "paralytic agents". In addition, Personal Reference Manager files were used as the database for the present review. References were selected on the basis of the bearing of their results on prevention of VAP.

\section{CATEGORISATION OF RECOMMENDATIONS European Task Force}

In the ETF guidelines [4], a panel of experts in the field of VAP from four European societies (the European Respiratory Society, the European Society of Intensive Care Medicine, the European Society of Clinical Microbiology and Infectious Diseases and the European Society of Anaesthesiology) provided an overview of the most important aspects under debate. Each section was classified according to the following categories: 1) what is not controversial; and 2) what is still controversial.
AFFILIATIONS

*Intensive Care Unit, Hospital Universitario de Canarias, La Laguna, Tenerife,

"Intensive Care Dept, Joan XXIII University Hospital, and ${ }^{+}$University Rovira i Virgili Medical School, Pere Virgili Health Institut, Tarragona, Spain

${ }^{\#}$ Critical Care Dept, Ghent University Hospital, Ghent, Belgium.

CORRESPONDENCE

L. Lorente

Intensive Care Unit

Hospital Universitario de Canarias $\mathrm{C} / \mathrm{Ofra} \mathrm{s} / \mathrm{n}$

La Laguna

Tenerife

38320

Spain

Fax: 3422662245

E-mail: lorentemartin@msn.com

Received

April 202007

Accepted after revision:

July 032007

\section{SUPPORT STATEMENT}

The present study was supported, in part, by a grant from $\mathrm{CB} / 06 / 06 / 0036$.

STATEMENT OF INTEREST

A statement of interest for J. Rello

can be found at

www.erj.ersjournals.com/misc/

statements.shtml

European Respiratory Journa Print ISSN 0903-1936 Online ISSN 1399-3003 


\section{Centers for Disease Control and Prevention}

In the CDC guidelines [5], each recommendation was categorised in accordance with the following classification: "category IA" if strongly recommended for implementation and firmly supported by well-designed experimental, clinical or epidemiological studies; "category IB" if strongly recommended for implementation and supported by certain clinical or epidemiological studies and by a sound theoretical rationale; "category $\mathrm{IC}^{\prime \prime}$ if required for implementation, as mandated by federal or state regulation or standard; "category II" if suggested for implementation and supported by suggestive clinical or epidemiological studies or by a strong theoretical rationale; "no recommendation; unresolved issue" in the case of practices for which insufficient evidence was available or if no consensus existed regarding their efficacy.

\section{Canadian Critical Care Society}

In the CCCS guidelines [6], the recommendations were classified according to the following terms: "recommended" if there were no reservations about endorsing an intervention; "considered" if there was evidence supporting an intervention but there were minor uncertainties about the benefits, harms, or costs; "no recommendation" if evidence regarding an intervention was inadequate or if there were major uncertainties about the benefits, harms or costs.

\section{American Thoracic Society and Infectious Diseases Society of America}

In the ATS-IDSA guidelines [7], the grading system for the evidence-based recommendations used was as follows: "level I" when the evidence was from well-conducted, randomised controlled trials; "level II" when the evidence came from welldesigned, controlled trials without randomisation (including cohort, patient series, and case-control studies); "level III" when it comes from case studies and expert opinion.

\section{NONPHARMACOLOGICAL MEASURES FOR PREVENTING VAP}

\section{Orotracheal versus nasotracheal intubation}

The use of nasotracheal intubation has been associated with a higher incidence of nosocomial sinusitis than orotracheal intubation [8-10], and sinusitis may predispose to VAP through the aspiration of infected secretions from the nasal sinuses, although causality between sinusitis and VAP has not been firmly established. Thus, orotracheal intubation should be chosen in patients who do not have contraindications for it.

\section{Monitoring endotracheal tube cuff pressure}

The pressure of the endotracheal tube cuff should be sufficiently high to avoid the loss of gas from the lower respiratory tract and the leakage of bacterial pathogens around the cuff into the lower respiratory tract. In a study by RELLO et al. [11], 83 consecutive intubated patients were evaluated. There was a trend toward a higher risk of pneumonia (relative risk 2.57, 95\% confidence interval (CI) 0.78-8.03) among patients with persistent intra-cuff pressures $<20 \mathrm{cmH}_{2} \mathrm{O}$. Among intubated patients not receiving antibiotics, persistent intra-cuff pressure $<20 \mathrm{cmH}_{2} \mathrm{O}$ was independently associated with the development of pneumonia (relative risk $4.23,95 \% \mathrm{CI}$ 1.12-15.92). Moreover, this pressure should be maintained at

\begin{tabular}{|c|c|c|c|c|}
\hline [Ref.] & [4] & [5] & [6] & [7] \\
\hline Publication yr & 2001 & 2004 & 2004 & 2005 \\
\hline Subglottic secretion drainage & Still controversial & $\|$ & Considered & I \\
\hline Early extubation & NR & IB & NR & $\|$ \\
\hline Avoid re-intubation & Not controversial & $\|$ & NR & 1 \\
\hline Noninvasive ventilation & Still controversial & $\|$ & NR & । \\
\hline Tracheostomy: early better than late & NR & NR & Insufficient evidence & NR \\
\hline Routine change of closed tracheal suctioning system & Still controversial & Unresolved & NO & NR \\
\hline Sterilisation or disinfection of respiratory devices & NR & IB & NR & NR \\
\hline Barrier measures & Not controversial & IA & NR & I \\
\hline Kinetic or standard beds & NR & Unresolved & Considered & NR \\
\hline Semirecumbent position $\left(30-45^{\circ}\right)$ & Not controversial & $\|$ & Recommended & 1 \\
\hline Feeding: post-pyloric better than gastric & Still controversial & Unresolved & NR & NR \\
\hline
\end{tabular}

HME: heat and moisture exchanger; HH: heated humidifier; IB: the evidence comes from certain clinical or epidemiological studies; II: the evidence comes from welldesigned, controlled trials without randomisation; NR: the guideline did not review this issue; I: the evidence is from well-conducted, randomised controlled trials; NO: the recommendation is of no use; IA: the evidence comes from well-designed experimental, clinical or epidemiological studies. 


\begin{tabular}{|c|c|c|c|c|c|}
\hline TABLE 2 & \multicolumn{5}{|c|}{$\begin{array}{l}\text { European Task Force (ETF), Centers for Disease Control and Prevention (CDC), Canadian Critical Care Society (CCCS) } \\
\text { and American Thoracic Society and Infectious Diseases Society of America (ATS-IDSA) recommendations regarding } \\
\text { pharmacological measures for ventilator-associated pneumonia }\end{array}$} \\
\hline \multicolumn{2}{|l|}{ [Ref.] } & [4] & [5] & [6] & [7] \\
\hline \multicolumn{2}{|c|}{ Publication yr } & 2001 & 2004 & 2004 & 2005 \\
\hline \multicolumn{2}{|c|}{ Preventive intravenous antibiotics } & Still controversial & Unresolved & Insufficient evidence & I at time of intubation \\
\hline \multicolumn{2}{|c|}{ Chlorhexidine oral rinse } & NR & II in cardiac surgery & NR & I in cardiac surgery \\
\hline \multicolumn{2}{|c|}{ Sucralfate better than ranitidine } & Still controversial & Unresolved & Insufficient evidence & I: is the same \\
\hline \multicolumn{2}{|c|}{ Avoidance of deep sedation and paralytic agents } & Not controversial & NR & NR & $\|$ \\
\hline
\end{tabular}

I: the evidence is from well-conducted, randomised controlled trials; NR: the guideline did not review this issue; II: the evidence is from well-designed, controlled trials without randomisation.

$<30 \mathrm{cmH}_{2} \mathrm{O}$ to prevent tracheal injury $[12,13]$. Thus, the intracuff pressure should be persistently maintained at 20$30 \mathrm{cmH}_{2} \mathrm{O}$.

\section{Subglottic secretions drainage}

Oropharyngeal secretions may descend into the trachea, accumulate above the endotracheal cuff and later progress to the lower respiratory tract, causing VAP. Investigators have attempted pre-emptively to remove these secretions with the goal of reducing microaspiration and the risk of VAP. Subglottic secretions drainage (SSD) is accomplished through use of a specially designed endotracheal or tracheostomy tube with a separate dorsal lumen that opens directly above the endotracheal or tracheostomy tube cuff. SSD has reduced the incidence of VAP in some studies [11, 14-16]; however, in other studies it has not been found to decrease the incidence of VAP $[17,18]$ or airway colonisation [19]. Maintaining the pressure of the endotracheal tube at $>20 \mathrm{cmH}_{2} \mathrm{O}$ and the concomitant role of antibiotics may explain these discrepancies.

The recommendation to use SSD was also supported by the results of a later meta-analysis developed by DEZFULIAN et al. [20], which evaluated 896 patients from five studies [14-18]. SSD appears to be effective in preventing VAP (relative risk $0.51,95 \%$ CI $0.37-0.71$ ) in patients expected to require $>72 \mathrm{~h}$ of mechanical ventilation; primarily by reducing early-onset pneumonia. Thus, the use of an endotracheal or tracheostomy tube with SSD should be recommended in patients expected to require $>72 \mathrm{~h}$ of mechanical ventilation.

\section{Avoiding delays in extubation}

The presence of an endotracheal tube increases the probability of aspiration of pathogens from the oropharynx into the lower airways and the probability of developing nosocomial pneumonia. The risk of developing VAP increases over time in mechanical ventilation [21-23]. Thus, the present authors recommend removal of endotracheal tubes from patients as soon as the clinical situation allows; the duration of intubation can be reduced by protocols to improve the use of sedation and to accelerate weaning.

\section{Avoiding re-intubation}

Re-intubation has been associated with the risk of VAP [24-26]. This fact may be due to an increased risk of aspiration of pathogens from the oropharynx by patients with subglottic dysfunction after several days of endotracheal intubation. Thus, re-intubation should be avoided as far as possible. The re-intubation rate can be reduced by the following measures: 1) improving planned extubations with the design of protocols to improve quality of weaning; 2) by the use of noninvasive mechanical ventilation; and 3) avoiding accidental removal of the endotracheal tube and monitoring the rate of accidental extubation, which according to the findings of several large series is $0.8-2.2$ per 100 endotracheal tube-days [27-29].

\section{Noninvasive mechanical ventilation}

In some studies [30-33], the use of noninvasive mechanical ventilation (NIMV) has been shown to reduce VAP incidence compared with invasive ventilation in patients who are in respiratory failure. The use of NIMV in weaning also reduced the VAP incidence in some studies [34-36], but not in another [37].

A recent meta-analysis published by BURNs et al. [38], which included 171 patients enrolled in five studies, analysed the 150 patients from four of the studies that reported the VAP rate [34-37]. BuRNs et al. [38] found that in comparison with invasive ventilation, the noninvasive form decreased VAP (relative risk $0.28,95 \%$ CI $0.09-0.85$ ), mortality (relative risk $0.41,95 \%$ CI $0.22-0.76$ ) and duration of mechanical ventilation (weighted mean difference -7.33 days, 95\% CI $-11.45-$ -3.22 days).

Thus, NIMV has been shown to be an effective alternative in patients with respiratory failure due to cardiogenic pulmonary oedema or chronic obstructive pulmonary disease, and in weaning; however, its role in pneumonia, acute respiratory distress syndrome and asthma is less clear. Besides, it is assumed that in comatose patient, NIMV is not an option. Therefore, more research is necessary into the indications for and standards of NIMV. 


\section{Early tracheostomy}

Prolonged intubation has been associated with complications such as laryngeal injury and tracheal stenosis [39-42], and conversion to tracheostomy has been proposed when the use of prolonged intubation is anticipated to avoid these complications.

Some studies have found early tracheostomy to be more greatly associated with a lower incidence of VAP than late tracheostomy [43, 44], though other studies comparing early with late tracheostomy or prolonged intubation have found no such association [45-52].

In a more recent meta-analysis by GRIFFITHS et al. [53], which enrolled 382 patients from five studies [44-48], early tracheostomy did not significantly decrease the risk of pneumonia (relative risk $0.90,95 \%$ CI $0.66-1.21$ ) or mortality (relative risk $0.79,95 \%$ CI $0.45-1.39$ ). However, early tracheostomy significantly reduced the duration of artificial ventilation (mean difference -8.5 days, 95\% CI -15.3- -1.7 days) and length of stay in intensive care (mean difference -15.3 days, 95\% CI -24.6--6.1 days). Thus, early tracheostomy should be performed in patients expected to require prolonged mechanical ventilation. Further studies are needed to clarify the timing of tracheostomy.

\section{Respiratory filters}

From 1952 to 1972, outbreaks of nosocomial pneumonia were associated with contamination of anaesthesia machines [5456]. To avoid VAP episodes linked to anaesthesia machine or to ventilator contamination, it was suggested that bacterial filters should be interposed in respiratory circuits, although it has not been proven that they diminish the incidence of VAP.

Contamination of the ventilator and the anaesthesia machine as the origin of nosocomial pneumonia is controversial. Some reports identify the anaesthesia circuit as a source of pneumonia [54-56], but none of them are conclusive, for a range of reasons. None presented a bacteriological demonstration of a cause-end-effect relationship; in addition, the study by TinNe et al. [55] reported that the same isolate of Pseudomonas aeruginosa responsible for an outbreak of post-operative pneumonia was cultured from the corrugated tubing of the anaesthesia machine and from manual ventilation bags. Also, in some studies [57-59], after the sterilisation of the anaesthesia machine and the anaesthesia circuit, the intentional contamination of the expiratory circuit was not followed by the contamination of the anaesthesia machine.

To avoid VAP due to the contamination of the ventilators, bacterial filters were inserted into the respiratory circuits. Previous studies have evaluated the effect of filters in circuits of anaesthesia machines and were unable to demonstrate that their use offered protection against the development of post-operative respiratory infection [60, 61]. The authors of both these studies believed that the anaesthesia machine was an unlikely source of infection.

In a randomised clinical trial [62], no significant differences were found in VAP incidence either with or without filters in the ventilator circuit; the authors found no significant differences in VAP incidence in the patients ventilated with or without filters ( 24.5 versus $21.5 \%, \mathrm{p}=0.58$ ). Thus, it can be concluded that filters should not be used routinely. However, according to the CDC recommendation, they should be used in patients with suspected or confirmed bacillary pulmonary tuberculosis undergoing mechanical ventilation [63].

\section{Routine change of ventilator circuits}

With the use of heated humidifiers $(\mathrm{HH})$, condensed liquid may appear in the ventilator circuits due to the difference in temperature between the inspiratory phase gas and the ambient air. This condensed liquid may become contaminated with microorganisms via different routes, either directly by a manipulation of the airway, or with the respiratory secretions of the patient. This contaminated liquid can enter the tracheobronchial tree via manipulations, such as respiratory secretion aspiration, change of the respirator location or patient bathing, and it may be associated with VAP.

Periodic changing of the ventilator circuits has been proposed as a way of avoiding VAP due to this condensed liquid, but the usefulness of the measure has been questioned over the years. In 1983, the CDC proposed changing of the ventilator circuit every $24 \mathrm{~h}$ [64] and, in 1994, they recommended extending the period to $48 \mathrm{~h}$ [65]. Later studies suggested that the period should be extended still further [66-71].

In all these studies the humidification was generated with an $\mathrm{HH}$. However, the effectiveness of the periodic changing of ventilator circuits in decreasing VAP incidence is even more doubtful when the humidification system used is a heat and moisture exchanger (HME), because this instrument avoids the condensation of liquid in ventilator circuits. Recently, a randomised study analysed VAP incidence in patients using a HME exclusively with and without periodic changing of ventilator circuits [72], finding no significant differences in VAP incidence (23.0 versus $22.9 \%, \mathrm{p}=0.98$ ), which suggested that routine circuit change when using a HME is also unnecessary. Thus, the ventilator circuits should not be changed routinely, only for a new patient or if they become soiled.

\section{Heat and moisture exchangers or heated humidifiers}

The use of mechanical ventilation with an artificial airway requires conditioning of the inspired gas. This is because medicinal gases are cold and dry, and when the upper airway is bypassed it cannot contribute to the natural heat and moisture exchange process of inspired gases. At low levels of inspired humidity, water is removed from the mucus and periciliary fluid by evaporation, causing a decrease in mucus clearance.

Artificial humidification of medicinal gases may be active or passive. In active humidifiers, called $\mathrm{HHs}$, the inspired gas passes across or over a heated water bath. Passive humidifiers, called artificial noses or HMEs, trap heat and humidity from the patient's exhaled gas and return some of it to the patient on the subsequent inhalation.

There is controversy about what constitutes the optimal humidity level of the inspired gas and about the appropriate humidification system. Some authors have advocated absolute humidity levels of 26-32 mg of water vapour per litre of gas and recommend the use of HMEs because these devices provide these levels. However, others advocate an absolute 
humidity level of $44 \mathrm{mg}$ of water vapour per litre of gas and recommend the use of $\mathrm{HHs}$ because they can condition inspired gas to this humidity level (programmed to deliver medicinal gas at a temperature of $37^{\circ} \mathrm{C}$ and a relative humidity of $100 \%)$.

In the review by WiLLIAMs et al. [73], the data from 200 relevant studies on respiratory tract physiology and humidification were plotted on a humidity exposure map. This review reveals that there have been few studies with human subjects and that the duration of most of them was only $12 \mathrm{~h}$. The trend of the map data suggests that mucociliary dysfunction can occur after 24-48 h with an absolute humidity level of $<32 \mathrm{mg}$ water vapour per litre, and that the optimal humidification model of inspired medicinal gas should be at body temperature and $100 \%$ relative humidity, containing $\sim 44 \mathrm{mg}$ water vapour per litre of gas; however, further research with exposure times $>24 \mathrm{~h}$ is needed to verify this proposition fully.

A randomised study conducted by HuRNi et al. [74] evaluated the morphological integrity of the respiratory epithelium of 41 patients receiving mechanical ventilation for $\geqslant 5$ days using either an $\mathrm{HH}$ at $32^{\circ} \mathrm{C}$ and a relative humidity of $100 \%$ or an HME as the humidification system. The group with HME showed a trend towards a greater damage of the respiratory epithelium than with $\mathrm{HH}$; however, it would be of interest to observe the result with a bigger sample size and using $\mathrm{HH}$ with a temperature of $37^{\circ} \mathrm{C}$ and a relative humidity of $100 \%$ (which would ensure the delivery of $\sim 44 \mathrm{mg}$ of water per litre of gas).

There is also controversy concerning the possible influence of these systems on the incidence of VAP. While one study reported a lower incidence of VAP associated with the use of HME [75], several studies found no significant differences between the two systems [74-85], and three studies found a lower incidence of VAP associated with $\mathrm{HH}$ [86-88].

A recent meta-analysis by KoLA et al. [89], which enrolled 1,378 patients from nine trials [74-82], found that the use of HME decreased the VAP rate (relative risk $0.7,95 \%$ CI $0.50-0.94$ ). However, only one of the studies included in the meta-analysis by KOLA et al. [89], the study by KIRTON et al. [75], reported a significantly lower incidence of VAP with HME compared with $\mathrm{HH}$. In addition, these meta-analyses did not include the nonrandomised studies by COHEN et al. [86] and BLIN et al. [87], which found significantly decreased VAP rates using $\mathrm{HH}$ compared with HME.

After the meta-analysis, two randomised studies found no significant differences in VAP rates associated with the use of $\mathrm{HH}$ or HME [84, 85]; in a randomised study of 104 patients requiring mechanical ventilation for $>5$ days, a lower incidence of VAP was found with the use of $\mathrm{HH}$ than with HME (15.69 versus $39.62 \% ; \mathrm{p}=0.006$ ) [88].

In addition to VAP, there are other important issues that must be considered when a passive humidifier is used. In one study, a lower incidence of tube occlusion, thick bronchial secretions and atelectasis was reported with $\mathrm{HH}$ than with HME [86]. Besides, the use of HME has been associated with increased airway resistance and dead space, thus HME could entail increased work-of-breathing [90-93].
Thus, more research is necessary to establish the optimal humidification level and system; however, the present authors recommend the use of $\mathrm{HME}$ in patients who are expected to need mechanical ventilation for $24-48 \mathrm{~h}$, and $\mathrm{HH}$ in patients expected requiring more prolonged ventilation.

\section{Closed tracheal suctioning system versus open tracheal suctioning system}

The suction of respiratory secretions is necessary in patients with an artificial airway (endotracheal intubation or tracheostomy) to remove respiratory secretions and to maintain the airway's permeability.

There are two kinds of respiratory secretion suctioning systems: 1) the open tracheal suctioning system (OTSS), which uses single-use suctioning catheters and must be disconnected from the respiratory circuit; and 2) the closed tracheal suctioning system (CTSS), which uses reusable suctioning catheters and does not require disconnection of the respiratory circuit. For these reasons, CTSS is presumed to offer advantages over OTSS, such as lower gasometric and haemodynamic impairment during the suction of respiratory secretions, which has been found in several studies [94-97], and a protective effect against VAP, although this latter finding is controversial because only one study has reported a lower incidence of VAP using CTSS [98]. Several other studies have not found significant differences in the incidence of VAP between the systems [99-105].

In two recent meta-analyses by VONBERG et al. [106] and JONGERDEN et al. [107], no significant difference was found in the incidence of VAP using either a CTSS or an OTSS.

One of the potential advantages of CTSS is that these systems can reduce exogenous VAP, that is, those infections caused by microorganisms that were not colonising the throat at the moment of diagnosis and reached the patient airway directly through the endotracheal tube. This decrease in the exogenous pneumonia rate could be due to the fact that CTSS avoids direct manipulations of the aspiration catheter, as it is protected by a plastic envelope. Nevertheless, in two recent randomised studies, no significant differences were found between the patients suctioning with CTSS or OTSS in terms of either total VAP incidence or exogenous VAP incidence [104, 105]. Thus, the evidence does not support the routine use of CTSS for prevention of VAP.

\section{Routine change of closed tracheal suctioning system}

The main restriction on the use of CTSS is its higher cost [94, $95,100,101,104]$, since the manufacturer recommends that the system should be changed completely each day. However, the need for this complete daily change has not been demonstrated.

VAP incidence did not increase in two studies [108, 109] in which the period for the change of CTSS was prolonged. KOLLEF et al. [108] did not report significant differences in VAP incidence between patients with and without routine 24-hourly change of CTSS. Nor were there significant differences in VAP incidence between patients with CTSS change every 48 or $24 \mathrm{~h}$ in the study by DARVAS and HAWKINS [109]. 
A randomised study recently evaluated the incidence of VAP and the suctioning cost, comparing OTSS and CTSS without daily change [105]. The CTSS used had two parts: 1) a suction catheter (enveloped in a protective plastic); with 2) a suction valve, detachable from the elbow and equipped with a rotating patient access valve (bronchoscope valve). This division into two parts means that the suctioning catheter and its protective plastic envelope can be disconnected and changed without changing the whole system (a partial change). The closed system that was used was not routinely changed unless it presented mechanical failure (e.g. valve dysfunction with air entering the protective catheter envelope or protective envelope breakage) or soiling (with blood or vomit), or when the patient needed re-intubation. On re-intubation or valve dysfunction, a total change of the system was performed. When the protective envelope became torn or soiled, a partial change of the system was performed (only the suctioning catheter and the protective envelope). When patients needed to be moved for a surgical or radiological procedure, they continued to use the same system. The authors found no differences in VAP incidence between the CTSS without complete daily change $(13.9 \%)$ and OTSS patients $(14.1 \%$, $\mathrm{p}=0.99)$; nor did tracheal suctioning costs differ significantly per patient-day between CTSS and OTSS ( $€ 2.3 \pm 3.7$ versus $€ 2.4 \pm 0.5, \mathrm{p}=0.96$ ); when length of mechanical ventilation was $>4$ days, costs were lower with CTSS than with OTSS $(€ 1.6 \pm 2.8$ versus $€ 2.5 \pm 0.5, \mathrm{p}<0.001)$. Some types of CTSS allow the possibility of partially changing the system (only the suctioning catheter and the protective envelope). With other types of CTSS, this partial change cannot be made and, in this case, the cost of each aspiration may not be lower. Thus, CTSS should not be routinely changed, only for a new patient or if it becomes soiled or spoiled.

\section{Sterilisation or disinfection of reusable respiratory devices}

Several outbreaks of nosocomial pneumonia have been reported due to various respiratory devices, such as nebulisers [110], resuscitation bags [111], respirometers [112], ventilator thermometers [113] and bronchoscopes [114]. Thus, reusable respiratory devices should be sterilised or disinfected for use in different patients to avoid cross-contamination and the development of VAP.

\section{Barrier measures}

Colonisation of the hands is a concern in healthcare workers [115-117], since it increases the risk of nosocomial infection by cross-colonisation with procedures, such as tracheal suctioning, manipulation of ventilatory circuits and bronchoscopy. The risk of cross-contamination can be reduced by using adequate barrier measures, such as hand washing, gloves, aprons and masks, to avoid contact with patients' secretions $[118,119]$. Thus, adequate barrier measures should be used for contact with the secretions of the patients.

\section{Kinetic beds}

Mechanically ventilated patients are often cared for in the supine position for extended periods of time. In this position, the functional residual capacity is decreased because of alveolar closure in dependent lung regions. Immobility may impair mucociliary clearance, with the accumulation of mucus in dependent lung zones. This can lead to atelectasis and respiratory infection of dependent lung regions. As standard practice, mechanically ventilated patients are usually turned every $2 \mathrm{~h}$ by the nursing staff. The potential benefits of kinetic beds are that they accomplish continuous turning of a patient to at least $40^{\circ}$ on each side and, in addition, can provide percussion and vibration therapy, with the goal of optimising mucociliary clearance and avoiding the accumulation of mucus in dependent lung zones.

The use of kinetic beds in place of standard beds was found to decrease VAP incidence in some studies [120-122], but not in others [123-129]. In the recent meta-analysis by DELANEY et al. [130], which included 1,169 patients from 15 trials, analysis of the 967 patients from the 10 studies that reported VAP rate [120-129] found that kinetic bed therapy reduced VAP incidence (odds ratio $0.38,95 \%$ CI $0.28-0.53$ ). However, kinetic bed therapy did not reduce mortality rate (odds ratio $0.96,95 \%$ CI 0.66-1.14), duration of mechanical ventilation (pooled standardised mean difference -0.14 days, 95\% CI -0.29 0.02 days), duration of intensive care unit stay (pooled standardised mean difference -0.064 days, 95\% CI $-0.21-$ 0.086 days) or duration of hospital stay (pooled standardised mean difference 0.05 days, 95\% CI -0.18-0.27 days). Besides this, most of the VAP diagnoses in kinetic bed therapy studies were made only on a clinical basis without microbiological cultures. In addition, the potential benefit of kinetic beds to decrease the incidence of atelectasis was not analysed. Additionally, many of the patients undergoing kinetic bed therapy showed complications, such as intolerance, unplanned extubation, loss of vascular lines, cardiac arrest, arrhythmia, problems with skeletal traction, and increased intracranial pressure. Thus, given the lack of consistent benefit and the poor methodological quality of the studies, it is not possible make a definitive recommendation regarding its use.

\section{Semirecumbent position (30-45)}

Some studies have found the semirecumbent position to be associated with lower levels of aspiration into the lower airways [131-133] and lower VAP incidence than the supine position [134-136]. A recent study by VAN NIEUWENHOVEN et al. [137] questioned the efficacy of this measure and its feasibility for daily practice. VAN NIEUWENHOVEN et al. [137] randomised 221 patients to a semirecumbent (with a backrest of $45^{\circ}$ ) or supine position (backrest of $10^{\circ}$ ), finding that the targeted semirecumbent position was not achieved in the conditions of the study and that the difference attained in the treatment position (28 versus $10^{\circ}$ ) did not reduce VAP incidence. The influence of enteral nutrition [134] might explain the discrepancies between authors regarding effectiveness. In the study by DRAKULOVIC et al. [134], the semirecumbent position reduced the incidence of VAP, especially in patients who receive enteral nutrition. Thus, the patients should remain in the semirecumbent position, mainly in patients receiving enteral nutrition. It is noteworthy that the position of the upper body of the patient should not be $<10^{\circ}$ at any time (including during basic care or transport).

\section{Gastric compared with post-pyloric feeding}

Gastro-oesophageal reflux may contribute to aspiration to lower airways and thus the risk of VAP. It was suggested that 
placement of a post-pyloric tube can reduce the risk of aspiration and VAP.

In some studies, there were not significant differences in VAP and mortality rates between patients with gastric or postpyloric feeding [138-144]. In the meta-analysis by MARIK and ZALOGA [145], which enrolled 522 patients from nine studies, analysis of the 422 patients from seven studies that reported the VAP rate [138-144] found that gastric feeding showed a trend to higher incidences of VAP (odds ratio 1.44, 95\% CI 0.84-2.46) and mortality (odds ratio 1.08, 95\% CI 0.69-1.68) than post-pyloric feeding; however, the differences were not statistically significant.

Thus, a definitive recommendation regarding the routine use of post-pyloric feeding is not possible; however, there are some patients who may benefit from post-pyloric feeding, such as patients who are unlikely to tolerate gastric feeding (those with severe head injuries with high intracranial pressure or severe respiratory failure requiring prone ventilation, or who have major burns) or those with high nutritional requirements (those who are severely malnourished or have major burns).

\section{PHARMACOLOGICAL MEASURES FOR PREVENTING VAP \\ Selective digestive decontamination}

Oropharyngeal colonisation has been identified as an independent risk factor of VAP. Modulation of oropharyngeal colonisation has been proposed by the use of selective digestive decontamination (SDD), which consists of the administration of nonabsorbable oral antibiotics (usually polymyxin, tobramycin and amphotericin B) applied topically to the oropharynge and stomach, together with the intravenous administration of cefotaxime.

Several large meta-analyses report that SDD decreases the rates of VAP and mortality [146-151]. Two meta-analyses have shown that this effect on the rate of VAP and mortality is greater in surgical and trauma than in medical patients [147, 148]. However, despite the measure's proven clinical benefits, its use has not been generalised worldwide. There are a number of possible explanations: many physicians are still unfamiliar with the practice; emerging antimicrobial resistance has been reported in some studies [152-154]; proper application is complex and requires bacteriological monitoring (since the use of SDD should be carefully monitored as a potential stimulus for further antimicrobial resistance); and its costeffectiveness is unclear. It is controversial whether the benefit is due to the concomitant parenteral administration of antibiotics within the first days of the regimen.

Afterwards, several randomised studies have found a lower incidence of VAP with SDD [155-158]; however, a lower mortality rate was not found in some studies [157, 158].

Failure to prevent VAP using iseganan [159] raises additional concerns in implementing SDD. Iseganan is a topical antimicrobial peptide active against Gram-positive bacteria, Gramnegative bacteria and yeasts. In the randomised study [159], the topical administration of iseganan did not reduce the incidence of VAP. Thus, given the lack of consistent benefit and the unclear cost-effectiveness, it is not possible to make a definitive recommendation regarding its use.

\section{Preventive administration of intravenous antibiotics}

The administration of antibiotic peri-intubation showed a protective effect of early VAP in a randomised trial and in at least one observational study [160, 161]; however, in other studies, the prolonged administration of antibiotics has been associated with a higher risk of VAP $[136,162,163]$. Thus, due to this and concerns of resistance development, the present authors do not recommend the preventive administration of intravenous antibiotics.

\section{Oral cleaning and decontamination}

In some studies, oral chlorhexidine decreased VAP incidence [164-166], but not in others [167]. In the study by FouRRIER et al. [164], 60 patients in a multidisciplinary intensive care unit were randomised to receive oral chlorhexidine or placebo; the VAP incidence was found to be lower in the treated group (odds ratio $0.27 ; 95 \%$ CI $0.07-0.96$ ). In the study by HOUSTON et al. [165], 561 patients undergoing cardiac surgery were randomised to receive chlorhexidine gluconate oral rinse or phenolic mixture; although the overall rate of VAP was not significantly lower in the chlorhexidine group (1.4 versus $3.0 \%$, $\mathrm{p}=0.21$ ), in patients intubated for $>24 \mathrm{~h}$, the decrease in VAP incidence in the chlorhexidine group was statistically significant (20 versus $70 \% ; \mathrm{p}=0.02$ ). In the study by DeRiso et al. [166], 353 patients undergoing cardiac surgery were randomised to receive chlorhexidine gluconate oral rinse or phenolic mixture; again, the VAP incidence was lower in the treated group (2.9 versus $9.4 \%, \mathrm{p}<0.05)$.

A recent meta-analysis by PINEDA et al. [168], which included 1,202 patients from four studies [164-167], reported that the use of oral decontamination with chlorhexidine did not significantly decrease either the incidence of VAP (odds ratio $0.42,95 \%$ CI $0.16-1.06$ ) or the mortality rate (odds ratio 0.77 , 95\% CI 0.28-2.11).

At about the same time, in a study by KoEman et al. [169], 385 patients needing mechanical ventilation for $\geqslant 48 \mathrm{~h}$ were randomised to oral decontamination with chlorhexidine, chlorhexidine-colistin or placebo. The daily risk of VAP was reduced in both treatment groups compared with placebo, as follows: chlorhexidine-placebo (hazard ratio $0.35,95 \%$ CI 0.16 0.79 ) and with chlorhexidine-colistin-placebo (hazard ratio $0.45,95 \%$ CI 0.22-0.92).

Again at a similar time, a study by MORI et al. [170] was published, which showed that the incidence of VAP in a group of 1,252 patients who received oral care (povidone-iodine solution in combination with a toothbrush) was lower than in a group of 414 patients who did not receive it.

Thus, it seems that chemical decontamination with chlorhexidine as a solitary intervention may be insufficient to decrease the risk of pneumonia in a significant way, and that thorough mechanical cleaning is necessary. Thus, the present authors recommend the use of chlorhexidine oral rinse in combination with through mechanical cleaning of the oral cavity. A survey of oral care practices in 59 European intensive care units has recently been published [171], which shows that oral care is considered very important. 


\section{Stress ulcer prophylaxis}

The controversy concerning the use of ranitidine or sucralfate for stress ulcer prophylaxis remains unresolved. In the study by CoOK et al. [172], 1,200 critically ill patients who required mechanical ventilation were randomised to receive sucralfate or ranitidine. Clinically important gastrointestinal bleeding was lower in the patients receiving ranitidine (relative risk 0.44, 95\% CI 0.21-0.92), but there were no significant differences between the groups in VAP rate, mortality rate, or duration of the ICU stay. However, in some studies, the use of ranitidine was associated with a higher risk of VAP than sucralfate [173-175], though not in other studies [172, 176-179]. In the meta-analysis by MESSORI et al. [180], analysis of the 1,825 patients from eight studies that reported VAP rate [172-179] showed that the use of ranitidine to prevent gastrointestinal bleeding increased the VAP incidence in comparison with sucralfate (odds ratio 1.35, 95\% CI 1.07-1.70); however, this meta-analysis was full of ill-designed and under-powered studies. Later, a prospective cohort study, published by BORSTAIN et al. [181], of 747 patients undergoing mechanical ventilation found that sucralfate use was associated with a higher risk of early onset VAP (odds ratio 1.81, 95\% CI 1.013.26).

Other possible agents for stress ulcer prophylaxis are protonpump inhibitors. Limited data exist on its clinical efficacy; however, available data indicate that proton-pump inhibitors can be efficacious [182-186]. In two prospective series of patients receiving omeprazole oral suspension [182, 183], with sizes of 75 and 60 patients, respectively, clinically significant gastrointestinal bleeding was not experienced. In a randomised trial with 67 patients, a greater rate of clinically important bleeding (31 versus $6 \%, \mathrm{p}<0.05$ ), and a trend to a greater rate of VAP patients (14 versus 3\%) was found in the patients given ranitidine intravenously versus omeprazole orally [184]. In a randomised clinical trial of 160 paediatric critically ill patients, there were no significant differences in the incidence of VAP and macroscopic stress ulcer bleeding using orally administered sucralfate oral, and i.v. administered ranitidine and omeprazole [185]. In a recent randomised trial with 359 patients, no significant differences were observed in the rate of clinically significant bleeding between the patients who received omeprazole oral suspension and i.v. cimetidine [186]. Thus, the present authors believe that stress bleeding prophylaxis can be obtained without increasing the risk of VAP with use of histamine-2 receptor antagonists, sucralfate or protonpump inhibitors.

\section{Avoidance of sedation and paralytic agents}

The influence of sedation as a risk factor for VAP has been documented in some studies [11, 135, 187]. In the study by KRESS et al. [187], in which 128 adult patients receiving mechanical ventilation were randomised either to daily interruption of sedative drug infusions until they were awake or were interrupted only at the discretion of the clinician, the daily interruption group had shorter duration of mechanical ventilation $(p<0.01)$ and length of intensive care unit stay $(p=0.02)$ than the latter group. In a prospective cohort study by CoOK et al. [21] of 1,014 mechanically ventilated patients, the use of paralytic agents was associated with VAP (risk ratio $=1.57,95 \% \mathrm{CI}=1.03-2.39)$. Thus, the present authors recommend avoidance of deep sedation and relaxation if the incidence of VAP is to be reduced.

\section{Conclusion}

Discrepancies between guidelines are probably due to the following two main reasons: 1) the clinical trials that are revised in each guideline; and 2) disagreement with the interpretation of clinical trials. In clinical practice, the implementation of evidence-based guidelines for VAP is very variable [188]. Main nonadherence reasons to recommendations of guidelines between physicians were disagreement with the interpretation of clinical trials and unavailability of resources [189, 190]; between nurses, the main nonadherence reasons were unavailability of resources and patient discomfort [191].

Clearly, the effect of these measures varies between institutions and case mixes. The 100,000 Lives campaign [192], endorsed by leading US agencies and societies, establishes that all ventilated patients should receive a ventilator bundle to reduce the incidence of ventilator-associated pneumonia and other adverse events, accompanied by the following four services: 1) elevation of the head of the bed to $30-45^{\circ}$; 2) daily "sedation vacation" and daily assessment of readiness for extubation; 3) peptic ulcer disease prophylaxis; and 4) deep vein thrombosis prophylaxis. Tables 1 and 2 summarise the recommendations of the European Task Force, Centers for Disease Control and Prevention, Canadian Critical Care Society, American Thoracic Society and Infectious Diseases Society of America, and the present authors' recommendations. In recent years, there has been a rapid increase in the number of country-specific ventilator-associated pneumonia guidelines in Europe, which vary in their coverage of different disease aspects and in their overall recommendations; the development of pan-European ventilator-associated pneumonia guidelines would rationalise the conflicting proposals [193]. These data would be useful to design a ventilatorassociated pneumonia care bundle to be implemented in European institutions.

\section{REFERENCES}

1 Leu HS, Kaiser DL, Mori M, Woolson RF, Wenzel RP. Hospital-acquired pneumonia. Attributable mortality and morbidity. Am J Epidemiol 1989; 129: 1258-1267.

2 Heyland DK, Cook DJ, Griffith L, Keenan SP, BrunBuisson C. The attributable morbidity and mortality of ventilator-associated pneumonia in the critically ill patient. The Canadian Critical Trial Group. Am J Respir Crit Care Med 1999; 159: 1249-1256.

3 Bercault N, Boulain N. Mortality rate attributable to ventilator-associated nosocomial pneumonia in an adult intensive care unit: a prospective case-control study. Crit Care Med 2001; 29: 2303-2309.

4 Torres A, Carlet J. Ventilator-associated pneumonia. European Task Force on ventilator-associated pneumonia. Eur Respir J 2001; 17: 1034-1045.

5 Centers for Disease Control and Prevention (CDC). Guidelines for prevention of healthcare-associated pneumonia 2003. MMRW 2004; 53: 1-36. 
6 Dodek P, Keenan S, Cook D, et al. Evidence-based clinical practice guideline for the prevention of ventilatorassociated pneumonia. Ann Intern Med 2004; 141: 305-313.

7 American Thoracic Society (ATS) and Infectious Diseases Society of America (IDSA). Guidelines for the management of adults with hospital-acquired, ventilator-associated, and healthcare-associated pneumonia. Am J Respir Crit Care Med 2005; 171: 388-416.

8 Holzapfel L, Chevret S, Madinier G. Influence of longterm oro or nasotracheal intubation on nosocomial maxillary sinusitis and pneumonia: results of a prospective, randomized, clinical trial. Crit Care Med 1993; 21 : 1132-1138.

9 Rouby JJ, Laurent P, Gosnach M, Cambau E, Lamas G, Zouaoui A. Risk factors and clinical relevance of nosocomial maxillarys sinusitis in the critically ill. Am J Respir Crit Care Med 1994; 150: 776-783.

10 Salord F, Gaussorgues P, Marti-Flich J, et al. Nosocomial maxillary sinusitis during mechanical ventilation: a prospective comparison of orotracheal versus the nasotracheal route for intubation. Intensive Care Med 1990; 16: 390-393.

11 Rello J, Sonora R, Jubert P, Artigas A, Rue M, Valles J. Pneumonia in intubated patients: role of respiratory airway care. Am J Respir Crit Care Med 1996; 154: 111-115.

12 Lewis FR Jr, Schiobohm RM, Thomas AN. Prevention of complications from prolonged tracheal intubation. Am J Surg 1978; 135: 452-457.

13 Wain JC. Postintubation tracheal stenosis. Chest Surg Clin N Am 2003; 13: 231-246.

14 Mahul P, Auboyer C, Jospe R, et al. Prevention of nosocomial pneumonia in intubated patients: respective role of mechanical subglottic secretions and stress ulcer prophylaxis. Intensive Care Med 1992; 18: 20-25.

15 Bo H, He L, Qu J. Influence of the subglottic secretion drainage on the morbidity of ventilator associated pneumonia in mechanically ventilated patients. Zhonghua Jie He He Hu Xi Za Zhi 2000; 23: 472-474.

16 Smulders $K$, van der Hoeven $H$, Weers-Pothoff $I$, Vandenbroucke-Grauls C. A randomized clinical trial of intermittent subglottic secretion drainage in patients receiving mechanical ventilation. Chest 2002; 121: 858-862.

17 Vallés J, Artigas A, Rello J, et al. Continuous aspiration of subglottic secretions in preventing ventilator-associated pneumonia. Ann Intern Med 1995; 122: 179-186.

18 Kollef MH, Skubas NJ, Sundt TM. A randomized clinical trial of continuous aspiration of subglottic secretions in cardiac surgery patients. Chest 1999; 116: 1339-1346.

19 Girou E, Buu-Hoi A, Stephan F, et al. Airway colonisation in long-term mechanically ventilated patients. Effect of semi-recumbent position and continuous subglottic suctioning. Intensive Care Med 2004; 30: 225-233.

20 Dezfulian C, Shojania K, Collard HR, Kim HM, Matthay MA, Saint S. Subglottic secretion drainage for preventing ventilator-associated pneumonia: a metaanalysis. Am J Med 2005; 118: 11-18.

21 Cook DJ, Walter SD, Cook RJ, et al. Incidence of and risk factors for ventilator-associated pneumonia in critically ill patients. Ann Intern Med 1998; 129: 433-440.
22 Torres A, Aznar R, Gatell JM, et al. Incidence, risk, and prognosis factors of nosocomial pneumonia in mechanically ventilated patients. Am Rev Respir Dis 1990; 142: 523-528.

23 Myny D, Depuydt P, Colardyn F, Blot S. Ventilatorassociated pneumonia in a tertiary care ICU: analysis of risk factors for acquisition and mortality. Acta Clin Belg 2005; 60: 114-121.

24 Torres A, Gatell JM, Aznar E, El-Ebiary M, Puig de la Bellacasa J, González J. Reintubation increases the risk of nosocomial pneumonia in patients needing mechanical ventilation. Am J Respir Crit Care Med 1995; 152: 137-141.

25 Leal-Noval SR, Márquez-Vacaro JA, García-Curiel A, et al. Nosocomial pneumonia in patients undergoing heart surgery. Crit Care Med 2000; 28: 935-940.

26 Kollef MH, von Harz B, Prentice D, et al. Patient transport from intensive care increases the risk of developing ventilator-associated pneumonia. Chest 1997; 112: 765-773.

27 Lorente L, Huidobro MS, Martín MM, Jiménez A, Mora ML. Accidental catheter removal in critically ill patients: a prospective and observational study. Crit Care 2004; 8: 229-233.

28 Chiang AA, Lee KC, Lee JC, Wei CH. Effectiveness of a continuous quality improvement program aiming to reduce unplanned extubation: a prospective study. Intensive Care Med 1996; 22: 1269-1271.

29 Carrión M, Ayuso D, Marcos M, et al. Accidental removal of endotracheal and nasogastric tubes and intravascular catheters. Crit Care Med 2000; 28: 63-66.

30 Nourdine K, Combes P, Carton MJ, Beuret P, Cannamela A, Ducreux JC. Does noninvasive ventilation reduce the ICU nosocomial infection risk? A prospective clinical survey. Intensive Care Med 1999; 25: 567-573.

31 Antonelli M, Conti G, Rocco M, et al. A comparison of noninvasive positive-pressure ventilation and conventional mechanical ventilation in patients with acute respiratory failure. $N$ Engl J Med 1998; 339: 429-435.

32 Girou E, Schortgen F, Delclaux C, et al. Association of noninvasive ventilation with nosocomial infections and survival in critically ill patients. JAMA 2000; 284: 2361-2367.

33 Carlucci A, Richard JC, Wysocki M, Lepage E, Brochard L, SRLF Collaborative Group on Mechanical Ventilation. Noninvasive versus conventional mechanical ventilation. An epidemiologic survey. Am J Respir Crit Care Med 2001; 163: 8748-8780.

34 Ferrer M, Esquinas A, Arancibia F, et al. Noninvasive ventilation during persistent weaning failure: a randomized controlled trial. Am J Respir Crit Care Med 2003 168: 70-76.

35 Chen J, Qiu D, Tao D. Time for extubation and sequential noninvasive mechanical ventilation in COPD patients with exacerbated respiratory failure who received invasive ventilation. Zhonghua Jie He He Hu Xi Za Zhi 2001; 24: 99-100.

36 Nava S, Ambrosino N, Clini E, et al. Noninvasive mechanical ventilation in the weaning of patients with respiratory failure due to chronic obstructive pulmonary disease. A randomized, controlled trial. Ann Intern Med 1998; 128: 721-728. 
37 Girault C, Daudenthun I, Chevron V, Tamion F, Leroy J, Bonmarchand G. Noninvasive ventilation as a systematic extubation and weaning technique in acute-on-chronic respiratory failure: a prospective, randomized controlled study. Am J Respir Crit Care Med 1999; 160: 86-92.

38 Burns KE, Adhikari NK, Meade MO. A meta-analysis of noninvasive weaning to facilitate liberation from mechanical ventilation. Can J Anaesth 2006; 53: 305-315.

39 Whited RE. A prospective study of laryngotracheal sequelae in long-term intubation. Laryngoscope 1984; 94 : 367-377.

40 Colice GL, Stukel TA, Dain B. Laryngeal complications of prolonged intubation. Chest 1989; 96: 877-884.

41 Gaynor EB, Greenberg SB. Untoward sequelae of prolonged intubation. Laryngoscope 1985; 95: 1461-1467.

42 Stauffer JL, Olson DE, Petty TL. Complications and consequences of endotracheal intubation and tracheotomy. A prospective study of 150 critically ill adult patients. Am J Med 1981; 70: 65-76.

43 Lesnik I, Rappaport W, Fulginiti J, Witzke D. The role of early tracheostomy in blunt, multiple organ trauma. Am Surg 1992; 58: 346-349.

44 Rumbak MJ, Newton M, Truncale T, Schwartz SW, Adams JW, Hazard PB. A prospective, randomized, study comparing early percutaneous dilational tracheotomy to prolonged translaryngeal intubation (delayed tracheotomy) in critically ill medical patients. Crit Care Med 2004; 32: 1689-1694.

45 Bouderka MA, Fakhir B, Bouaggad A, Hmamouchi B, Hamoudi D, Harti A. Early tracheostomy versus prolonged endotracheal intubation in severe head injury. J Trauma 2004; 57: 251-254.

46 Rodríguez JL, Steinberg SM, Luchetti FA, Gibbons KJ, Taheri PA, Flint LM. Early tracheostomy for primary airway management in the surgical critical care setting. Surgery 1990; 108: 655-659.

47 Saffle JR, Morris SE, Edelman L. Early tracheostomy does not improve outcome in burn patients. J Burn Care Rehabil 2002; 23: 431-438.

48 Dunham CM, LaMonica C. Prolonged tracheal intubation in the trauma patient. J Trauma 1984; 24: 120-124.

49 Brook AD, Sherman G, Malen J, Kollef MH. Early versus late tracheostomy in patients who require prolonged mechanical ventilation. Am J Crit Care 2000; 9: 352-359.

50 Niederman MS, Ferranti RD, Zeigler A, Merrill WW, Reynolds HY. Respiratory infection complicating longterm tracheostomy. The implication of persistent gramnegative tracheobronchial colonization. Chest 1984; 85: 39-44.

51 El-Naggar M, Sadagopan S, Levine H, Kantor H, Collins VJ. Factors influencing choice between tracheostomy and prolonged translaryngeal intubation in acute respiratory failure: a prospective study. Anesth Analg 1976; 55: 195-201.

52 Sugerman HJ, Wolfe L, Pasquale MD, et al. Multicenter, randomized, prospective trial of early tracheostomy. J Trauma 1997; 43: 741-747.

53 Griffiths J, Barber VS, Morgan L, Young JD. Systematic review and meta-analysis of studies of the timing of tracheostomy in adult patients undergoing artificial ventilation. BMJ 2005; 330: 1243-1246.
54 Phillips I, Spencer G. Pseudomonas aeruginosa crossinfection due to contaminated respiratory apparatus. Lancet 1965; 2: 1325-1327.

55 Tinne JE, Gordon AM, Bain WH, Mackey WA. Crossinfection by Pseudomonas aeruginosa as a hazard of intensive surgery. BMJ 1967; 4: 313-315.

56 Beck A, Zadeh JA. Infection by anaesthetic apparatus. Lancet 1968; 1: 533-534.

57 Du Moulin GC, Saubermann AJ. The anesthesia machine and circle system are not likely to be sources of bacterial contamination. Anesthesiology 1977; 47: 353-358.

58 Pandit SK, Mehta S, Agarwal SC. Risk of cross infection from inhalation anesthetic equipment. Br J Anaesth 1967; 39: 838-844.

59 Ping FC, Oulton JL, Smith JA. Bacterial filters: are they necessary on anaesthetic machines? Can Anaesth Soc J 1979; 26: 415-419.

60 Garibaldi RA, Britt MR, Webster C, Pace NL. Failure of bacterial filters to reduce the incidence of pneumonia after inhalation anesthesia. Anesthesiology 1981; 54: 364-368.

61 Feeley TW, Hamilton WK, Xavier B, Moyers J, Eger EI. Sterile anesthesia breathing circuits do not prevent postoperative pulmonary infection. Anesthesiology 1981; 54: 369-372.

62 Lorente L, Lecuona M, Málaga J, Revert C, Mora ML, Sierra A. Bacterial filters in respiratory circuits: an unnecessary cost? Crit Care Med 2003; 31: 2126-2130.

63 Centers for Disease Control and Prevention. Guidelines for preventing the transmission of Mycobacterium tuberculosis in health-care facilities, 1994. MMWR 1994; 43: $1-132$.

64 Centers for Disease Control and Prevention. Guidelines for prevention of nosocomial pneumonia. Am J Infect Control 1983; 11: 230-244.

65 Centers for Disease Control and Prevention. Guidelines for prevention of nosocomial pneumonia. Am J Infect Control 1994; 22: 247-292.

66 Fink JB, Krause SA, Barrett L, Schaaff D, Alex CG. Extending ventilator circuit change interval beyond 2 days reduces the likelihood of ventilator-associated pneumonia. Chest 1998; 113: 405-411.

67 Han JN, Liu YP, Ma S, et al. Effects of decreasing the frequency of ventilator circuit changes to every 7 days on the rate of ventilator-associated pneumonia in a Beijing hospital. Respir Care 2001; 46: 891-896.

68 Gastmeier P, Wendt C, Ruden H. Breathing circuit exchange in intensive care. Once daily once weekly? Anaesthesist 1997; 46: 943-948.

69 Long MN, Wickstrom G, Grimes A, Benton CF, Belcher B, Stamm AM. Prospective, randomized study of ventilator associated pneumonia in patients with one versus three ventilator circuit changes per week. Infect Control Hosp Epidemiol 1996; 17: 14-19.

70 Hess D, Burns E, Romagnoli D, Kacmarek RM. Weekly ventilator circuit changes. A strategy to reduce costs without affecting pneumonia rates. Anesthesiology 1995; 82: 903-911.

71 Kotilainen HR, Keroac MA. Cost analysis and clinical impact of weekly ventilator circuit changes in patients in intensive care unit. Am J Infect Control 1997; 25: 117-120. 
72 Lorente L, Lecuona M, Galván R, Ramos MJ, Mora ML, Sierra A. Periodically changing ventilator circuits is not necessary to prevent ventilator-associated pneumonia when a heat and moisture exchanger it is used. Infect Control Hosp Epidemiol 2004; 25: 1077-1082.

73 Williams R, Rankin N, Smith T, Galler D, Seakins P. Relationship between the humidity and temperature of inspired gas and the function of the airway mucosa. Crit Care Med 1996; 24: 1920-1929.

74 Hurni JM, Feihl F, Lazor R, Leuenberger P, Perret C. Safety of combined heat and moisture exchanger filters in long-term mechanical ventilation. Chest 1997; 111: 686-691.

75 Kirton OC, De Haven B, Morgan J, Morejon O, Civetta J. A prospective, randomized comparison of an in-line heat moisture exchange filter and heated wire humidifiers. Rates of ventilator-associated early-onset (communityacquired) or late-onset (hospital-acquired) pneumonia and incidence of endotracheal tube occlusion. Chest 1997; 112: 1055-1059.

76 Martin C, Perrin G, Gevaudan MJ, Saux P, Gouin F. Heat and moisture exchangers and vaporizing humidifiers in the intensive care unit. Chest 1990; 97: 144-149.

77 Roustan JP, Kienlen J, Aubas S, Du Cailar J. Comparison of hydrophobic heat and moisture exchangers with heated humidifier during prolonged mechanical ventilation. Intensive Care Med 1992; 18: 97-100.

78 Dreyfuss D, Djedaïni K, Gros I, et al. Mechanical ventilation with heated humidifiers or heat and moisture exchangers: effects on patient colonization and incidence of nosocomial pneumonia. Am J Respir Crit Care Med 1995; 151: 986-992.

79 Branson R, Davis K, Campbell RS, Johnson DJ, Porembka DT. Humidification in the intensive care unit. Prospective study of a new protocol utilizing heated humidification and a hygroscopic condenser humidifier. Chest 1993; 104: 1800-1805.

80 Boots RJ, Howe S, George N, Harris FM, Faoagali J. Clinical utility of hygroscopic heat and moisture exchangers in intensive care patients. Crit Care Med 1997; 25: 1707-1712.

81 Kollef $\mathrm{MH}$, Shapiro SD, Boyd V, et al. A randomized clinical trial comparing an extended-use hygroscopic condenser humidifier with heated-water humidification in mechanically ventilated patients. Chest 1998; 113: 759-767.

82 Memish ZA, Oni GA, Djazmati W, Cunningham G, Mah MW. A randomized trial to compare the effects of a heat and moisture exchanger with a heated humidifying system on the occurrence rate of ventilator-associated pneumonia. Am J Infect Control 2001; 29: 301-305.

83 Misset B, Escudier B, Rivara D, Leclercq B, Nitenberg G. Heat and moisture exchanger vs heated humidifier during long-term mechanical ventilation. A prospective randomized study. Chest 1991; 100: 160-163.

84 Lacherade JC, Auburtin M, Cerf C, et al. Impact of humidification systems on ventilator-associated pneumonia: a randomized multicenter trial. Am J Respir Crit Care Med 2005; 172: 1276-1282.

85 Boots RJ, George N, Faoagali JL, Druery J, Dean K, Heller RF. Double-heater-wire circuits and heat- and moisture exchangers and the risk of ventilator-associated pneumonia. Crit Care Med 2006; 34: 687-693.

86 Cohen IL, Weinberg PF, Alan I, Rowinsky GS. Endotracheal tube occlusion associated with the use of heat and moisture exchangers in the intensive care unit. Crit Care Med 1988; 16: 277-279.

87 Blin F, Fraïsse F, Chauveau P, et al. Incidence of nosocomial pneumonias among 1788 ventilated patients in $6 \mathrm{ICU}$ according to the type of humidification used. Intensive Care Med 1996; 22: Suppl. 1, S324.

88 Lorente L, Lecuona M, Jiménez A, Mora ML, Sierra A. Ventilator-associated pneumonia using a heated humidifier or a heat and moisture exchanger-randomized controlled trial [ISRCTN88724583]. Crit Care 2006; 10: R116.

89 Kola A, Eckmanns T, Gastmeier P. Efficacy of heat and moisture exchangers in preventing ventilator-associated pneumonia: meta-analysis of randomized controlled trials. Intensive Care Med 2005; 31: 5-11.

90 Buckley PM. Increase in resistance of in-line breathing filters in humidified air. Br J Anaesth 1984; 56: 637-643.

91 Chiaranda M, Verona L, Pinamonti O, Dominioni L, Minoja G, Conti G. Use of heat and moisture exchanging (HME) filters in mechanically ventilated ICU patients: influence on airway flow-resistance. Intensive Care Med 1993; 19: 462-466.

92 Eckerbom B, Lindholm CE. Performance evaluation of six heat and moisture exchangers according to the Draft International Standard (ISO/DIS 9360). Acta Anaesthesiol Scand 1990; 34: 404-409.

93 French CJ, Bellomo R, Buckmaster J. Effect of ventilation equipment on imposed work of breathing. Crit Care Resusc 2001; 3: 148-152.

94 Carlon GC, Fox SJ, Ackerman NJ. Evaluation of a closedtracheal suction system. Crit Care Med 1987; 15: 522-525.

95 Zielmann S, Grote R, Sydow M, Radke J, Burchardi H. Endotracheal suctioning using a 24-hour continuous system. Can costs and waste products be reduced? Anaesthesist 1992; 41: 494-498.

96 Clark AP, Winslow EH, Tyler DO, White KM. Effects of endotracheal suctioning on mixed venous oxygen saturation and heart rate in critically ill adults. Heart Lung 1990; 19: 552-557.

97 Bettstetter $\mathrm{H}$. Indications for the use of closed endotracheal suction. Artificial respiration with high positive end-expiratory pressure. Anaesthesist 1994; 43: 359-363.

98 Combes P, Fauvage B, Oleyer C. Nosocomial pneumonia in mechanically ventilated patients, a prospective randomised evaluation of the Stericath closed suctioning system. Intensive Care Med 2000; 26: 878-882.

99 Johnson KL, Kearney PA, Johnson SB, Niblett JB, McMillan NL, McClain RE. Closed versus open endotracheal suctioning: cost and physiologic consequences. Crit Care Med 1994; 22: 658-666.

100 Adams DH, Hughes M, Elliott TS. Microbial colonization of closed-system catheters used in liver transplant patients. Intensive Crit Care Nurs 1997; 13: 72-76.

101 Cordero L, Sananes M, Ayers LW. Comparison of a closed (Trach Care MAC) with an open endotracheal suction system in small premature infants. J Perinatol 2000; 20: 151-156. 
102 Zeitoun SS, de Barros AL, Diccini S. A prospective, randomized study of ventilator-associated pneumonia in patients using a closed vs. open suction system. J Clin Nurs 2003; 12: 484-489.

103 Deppe SA, Kelly JW, Thoi LL, et al. Incidence of colonization, nosocomial pneumonia, and mortality in critically ill patients using a Trach Care closed-suction system versus an open-suction system: prospective, randomized study. Crit Care Med 1990; 18: 1389-1393.

104 Lorente L, Lecuona M, García C, Mora ML, Sierra A. Ventilator-associated pneumonia using a closed versus an open tracheal suction system. Crit Care Med 2005; 33: 115-119.

105 Lorente L, Lecuona M, Jiménez A, Mora ML, Sierra A. Tracheal suction by closed system without daily change versus open system. Intensive Care Med 2006; 32: 538-544.

106 Vonberg RP, Eckmanns T, Welte T, Gastmeier P. Impact of the suctioning system (open vs. closed) on the incidence of ventilation-associated pneumonia: metaanalysis of randomized controlled trials. Intensive Care Med 2006; 32: 1329-1335.

107 Jongerden IP, Rovers MM, Grypdonck MH, Bonten MJ. Open and closed endotracheal suction systems in mechanically ventilated intensive care patients: a metaanalysis. Crit Care Med 2007; 35: 260-270.

108 Kollef MH, Prentice D, Shapiro SD, et al. Mechanical ventilation with or without daily changes of in-line suction catheters. Am J Respir Crit Care Med 1997; 156: 466-472.

109 Darvas JA, Hawkins LG. The closed tracheal suction catheter: 24 hour or 48 hour change? Aust Crit Care 2003; 16: 86-92.

110 Reinarz JA, Pierce AK, Mays BB, Sanford JP. The potential role of inhalation therapy equipment in nosocomial pulmonary infection. J Clin Invest 1965; 44: 831-839.

111 Van Der Zwet WC, Parlevliet GA, Savelkoul PH, et al. Outbreak of Bacillus cereus infections in a neonatal intensive care unit traced to balloons used in manual ventilation. Clin Microbiol 2000; 38: 4131-4136.

112 Irwin RS, Demers RR, Pratter MR, et al. An outbreak of Acinetobacter infection associated with the use of a ventilator spirometer. Respir Care 1980; 25: 232-237.

113 Rogues AM, Maugein J, Allery A, et al. Electronic ventilator temperature sensors as a potential source of respiratory tract colonization with Stenotrophomonas maltophilia. J Hosp Infect 2001; 49: 289-292.

114 Wheeler PW, Lancaster D, Kaiser AB. Bronchopulmonary cross-colonization and infection related to mycobacterial contamination of suction valves of bronchoscopes. J Infect Dis 1989; 159: 954-958.

115 Larson EL. Persistent carriage of gram-negative bacteria on hands. Am J Infect Control 1981; 9: 112-119.

116 Adams BG, Marrie TJ. Hand carriage of aerobic gramnegative rods may not be transient. J Hyg (Lond) 1982; 89: 33-46.

117 Casewell M, Phillips I. Hands as route of transmission for Klebsiella species. BMJ 1977; 2: 1315-1317.

118 Steere AC, Mallison GF. Handwashing practices for the prevention of nosocomial infections. Ann Intern Med 1975; 83: 683-690.
119 Klein BS, Perloff WH, Maki DG. Reduction of nosocomial infection during pediatric intensive care by protective isolation. N Engl J Med 1989; 320: 1714-1721.

120 Fink M, Helsmoortel CM, Stein KL, Lee PC, Cohn SM. The efficacy of an oscillating bed in the prevention of lower respiratory tract infection in critically ill victims of blunt trauma. A prospective study. Chest 1990; 97: 132-137.

121 Ahrens T, Kollef M, Stewart J, Shannon W. Effect of kinetic therapy on pulmonary complications. Am J Crit Care 2004; 13: 376-383.

122 Kirschenbaum L, Azzi E, Sfeir T, Tietjen P, Astiz M. Effect of continuous lateral rotational therapy on the prevalence of ventilator-associated pneumonia in patients requiring long-term ventilatory care. Crit Care Med 2002; 30: 1983-1986.

123 Whiteman K, Nachtmann L, Kramer D, Sereika S, Bierman M. Effects of continuous lateral rotation therapy on pulmonary complications in liver transplant patients. Am J Crit Care 1995; 4: 133-139.

124 Gentilello L, Thompson DA, Tonnesen AS, et al. Effect of a rotating bed on the incidence of pulmonary complications in critically ill patients. Crit Care Med 1988; 16: 783-786.

125 Demarest GB, Schmidt-Nowara WW, Vance LW, Altman AR. Use of the kinetic treatment table to prevent the pulmonary complications of multiple trauma. West $J$ Med 1989; 150: 35-38.

126 Summer W, Curry P, Haponik EF, Nelson S, Elston R. Continuous mechanical turning of intensive care unit patients shortens length of stay in some diagnosticrelated groups. J Crit Care 1989; 4: 45-53.

127 deBoisblanc B, Castro M, Everret B, Grender J, Walker CD, Summer WR. Effect of air-supported, continuous, postural oscillation on the risk of early ICU pneumonia in nontraumatic critical illness. Chest 1993; 103: 1543-1547.

128 Traver GA, Tyler ML, Hudson LD, Sherrill DL, Quan SF. Continuous oscillation: outcome in critically ill patients. J Crit Care 1995; 10: 97-103.

129 MacIntyre N, Helms M, Wunderink R, Schmidt G, Sahn SA. Automated rotational therapy for the prevention of respiratory complications during mechanical ventilation. Respir Care 1999; 44: 1447-1451.

130 Delaney A, Gray H, Laupland KB, Zuege DJ. Kinetic bed therapy to prevent nosocomial pneumonia in mechanically ventilated patients: a systematic review and metaanalysis. Crit Care 2006; 10: R70.

131 Torres A, Serra-Batlles J, Ros E, et al. Pulmonary aspiration of gastric contents in patients receiving mechanical ventilation: the effect of body position. Ann Intern Med 1992; 116: 540-543.

132 Orozco-Levi M, Torres A, Ferrer M, et al. Semirecumbent position protects from pulmonary aspiration but not completely from gastroesophageal reflux in mechanically ventilated patients. Am J Respir Crit Care Med 1995; 152: 1387-1390.

133 Ibanez J, Penafiel A, Raurich JM, Marse P, Jorda R, Mata F. Gastroesophageal reflux in intubated patients receiving enteral nutrition: effect of supine and semirecumbent positions. J Parenter Enteral Nutr 1992; 16: 419-422. 
134 Drakulovic MB, Torres A, Bauer TT, Nicolas JM, Nogue S, Ferrer M. Supine body position as a risk factor for nosocomial pneumonia in mechanically ventilated patients: a randomised trial. Lancet 1999; 354: 1851-1858.

135 Fernandez-Crehuet R, Diaz-Molina C, de Irala J, Martinez-Concha D, Salcedo-Leal I, Masa-Calles J. Nosocomial infection in an intensive-care unit: identification of risk factors. Infect Control Hosp Epidemiol 1997; 18: 825-830.

136 Kollef $\mathrm{MH}$. Ventilator-associated pneumonia. A multivariate analysis. JAMA 1993; 270: 1965-1970.

137 van Nieuwenhoven CA, Vandenbroucke-Grauls C, van Tiel FH, et al. Feasibility and effects of the semirecumbent position to prevent ventilator-associated pneumonia: a randomized study. Crit Care Med 2006; 34: 396-402.

138 Davies AR, Froomes PRA, French CJ, et al. Randomized comparison of nasojejunal and nasogastric feeding in critically ill patients. Crit Care Med 2002; 30: 586-590.

139 Kearns PJ, Chin D, Mueller L, Wallace K, Jensen WA, Kirsch CM. The incidence of ventilator-associated pneumonia and success in nutrient delivery with gastric versus small intestinal feeding: a randomized clinical trial. Crit Care Med 2000; 28: 1742-1746.

140 Neumann DA, DeLegge MH. Gastric versus small-bowel tube feeding in the intensive care unit: a prospective comparison of efficacy. Crit Care Med 2002; 30: 1436-1438.

141 Day L, Stotts NA, Frankfurt A, et al. Gastric versus duodenal feeding in patients with neurological disease: a pilot study. J Neurosci Nurs 2001; 33: 155-159.

142 Kortbeek JB, Haigh PI, Doig C. Duodenal versus gastric feeding in ventilated blunt trauma patients: a randomized controlled trial. J Trauma 1999; 46: 992-998.

143 Montecalvo MA, Steger KA, Farber HW, et al. Nutritional outcome and pneumonia in critical care patients randomized to gastric versus jejunal tube feedings. The Critical Care Research Team. Crit Care Med 1992; 20: 1377-1387.

144 Montejo JC, Grau T, Acosta J, et al. Multi-center, prospective, randomized, single-blind study comparing the efficacy and gastrointestinal complications of early jejunal feeding with early gastric feeding in critically ill patients. Crit Care Med 2002; 30: 796-800.

145 Marik PE, Zaloga GP. Gastric versus post-pyloric feeding: a systematic review. Crit Care 2003; 7: R46-R51.

146 Hurley JC. Prophylaxis with enteral antibiotics in ventilated patients: selective decontamination or selective cross-infection? Antimicrob Agents Chemother 1995; 39: 941-947.

147 D’Amico R, Pifferi S, Leonetti C, Torri V, Tinazzi A, Liberati A. Effectiveness of antibiotic prophylaxis in critically ill adult patients: systematic review of randomised controlled trials. BMJ 1998; 316: 1275-1285.

148 Nathens AB, Marshall JC. Selective decontamination of the digestive tract in surgical patients: a systematic review of the evidence. Arch Surg 1999; 134: 170-176.

149 Tonnesen EK, Toft P. Antibiotic prophylaxis in adult critically ill patients in intensive care units. Ugeskr Laeger 1999; 161: 15-17.

150 Van Nieuwenhoven CA, Buskens E, van Tiel FH, Bonten MJ. Relationship between methodological trial quality and the effects of selective digestive decontamination on pneumonia and mortality in critically ill patients. JAMA 2001; 286: 335-340.

151 Liberati A, D'Amico R, Pifferi S, Torri V, Brazzi L. Antibiotic prophylaxis to reduce respiratory tract infections and mortality in adults receiving intensive care. Cochrane Database Syst Rev 2004; 1: CD000022.

152 Verwaest C, Verhaegen J, Ferdinande $\mathrm{P}$, et al. Randomized, controlled trial of selective digestive decontamination in 600 mechanically ventilated patients in a multidisciplinary intensive care unit. Crit Care Med 1997; 25: 63-71.

153 Misset B, Kitzis MD, Conscience G, Goldstein F, Fourrier A, Carlet J. Mechanisms of failure to decontaminate the gut with polymixin $\mathrm{E}$, gentamicin and amphotericin B in patients in intensive care. Eur J Clin Microbiol Infect Dis 1994; 13: 165-170.

154 Al Naiemi N, Heddema ER, Bart A, et al. Emergence of multidrug-resistant Gram-negative bacteria during selective decontamination of the digestive tract on an intensive care unit. J Antimicrob Chemother 2006; 58: 853-856.

155 de Jonge E, Schultz MJ, Spanjaard L, et al. Effects of selective decontamination of digestive tract on mortality and acquisition of resistant bacteria in intensive care: a randomised controlled trial. Lancet 2003; 362: 1011-1016.

156 de La Cal MA, Cerda E, Garcia-Hierro P, et al. Survival benefit in critically ill burned patients receiving selective decontamination of the digestive tract: a randomized, placebo-controlled, double-blind trial. Ann Surg 2005; 241: 424-430.

157 Krueger WA, Lenhart FP, Neeser G, et al. Influence of combined intravenous and topical antibiotic prophylaxis on the incidence of infections, organ dysfunctions, and mortality in critically ill surgical patients: a prospective, stratified, randomized, double-blind, placebo-controlled clinical trial. Am J Respir Crit Care Med 2002; 166: 1029-1037.

158 Stoutenbeek CP, van Saene HK, Little RA, Whitehead A, for the Working Group on Selective Decontamination of the Digestive Tract. Effect of selective decontamination of the digestive tract on mortality in multiple trauma patients: a multicenter randomized controlled trial. Intensive Care Med 2007; 33: 261-270.

159 Kollef M, Pittet D, Sanchez Garcia M, et al. A randomized double-blind trial of iseganan in prevention of ventilatorassociated pneumonia. Am J Respir Crit Care Med 2006; 173: 91-97.

160 Sirvent JM, Torres A, El-Ebiary M, Castro P, de Batlle J, Bonet A. Protective effect of intravenously administered cefuroxime against nosocomial pneumonia in patients with structural coma. Am J Respir Crit Care Med 1997; 155 1729-1734.

161 Rello J, Diaz E, Roque M, Valles J. Risk factors for developing pneumonia within 48 hours of intubation. Am J Respir Crit Care Med 1999; 159: 1742-1746.

162 Trouillet JL, Chastre J, Vuagnat A, et al. Ventilatorassociated pneumonia caused by potentially drug-resistant bacteria. Am J Respir Crit Care Med 1998; 157: 531-539.

163 Ewig S, Torres A, El-Ebiary M, et al. Bacterial colonization patterns in mechanically ventilated patients with traumatic and medical head injury. Incidence, risk factors, and association with ventilator-associated pneumonia. Am J Respir Crit Care Med 1999; 159: 188-198. 
164 Fourrier F, Cau-Pottier E, Boutigny H, RousselDelvallez M, Jourdain M, Chopin C. Effects of dental plaque antiseptic decontamination on bacterial colonization and nosocomial infections in critically ill patients. Intensive Care Med 2000; 26: 1239-1247.

165 Houston S, Hougland P, Anderson JJ, LaRocco M, Kennedy V, Gentry LO. Effectiveness of $0.12 \%$ chlorhexidine gluconate oral rinse in reducing prevalence of nosocomial pneumonia in patients undergoing heart surgery. Am J Crit Care 2002; 11: 567-570.

166 DeRiso AJ, Ladowski JS, Dillon TA, Justice JW, Peterson AC. Chlorhexidine gluconate $0.12 \%$ oral rinse reduces the incidence of total nosocomial respiratory infection and nonprophylactic systemic antibiotic use in patients undergoing heart surgery. Chest 1996; 109: 1556-1561.

167 Fourrier F, Dubois D, Pronnier P, et al. Effect of gingival and dental plaque antiseptic decontamination on nosocomial infections acquired in the intensive care unit: a double-blind placebo-controlled multicenter study. Crit Care Med 2005; 33: 1728-1735.

168 Pineda LA, Saliba RG, El Solh AA. Effect of oral decontamination with chlorhexidine on the incidence of nosocomial pneumonia: a meta-analysis. Crit Care 2006; 10: R35.

169 Koeman M, van der Ven AJ, Hak E, et al. Oral decontamination with chlorhexidine reduces the incidence of ventilator-associated pneumonia. Am J Respir Crit Care Med 2006; 173: 1348-1355.

170 Mori H, Hirasawa H, Oda S, Shiga H, Matsuda K, Nakamura M. Oral care reduces incidence of ventilatorassociated pneumonia in ICU populations. Intensive Care Med 2006; 32: 230-236.

171 Rello J, Koulenti D, Blot S, et al. Oral care practices in intensive care units: a survey of 59 European ICUs. Intensive Care Med 2007; 33: 1066-1070.

172 Cook D, Guyatt G, Marshall J, et al. A comparison of sucralfate and ranitidine for the prevention of upper gastrointestinal bleeding in patients requiring mechanical ventilation. Canadian Critical Care Trials Group. N Engl J Med 1998; 338: 791-797.

173 Eddleston JM, Vohra A, Scott P, et al. A comparison of the frequency of stress ulceration and secondary pneumonia in sucralfate- or ranitidine-treated intensive care unit patients. Crit Care Med 1991; 19: 1491-1496.

174 Prod'hom G, Leuenberger P, Koerfer J, et al. Nosocomial pneumonia in mechanically ventilated patients receiving antacid, ranitidine, or sucralfate as prophylaxis for stress ulcer. A randomized controlled trial. Ann Intern Med 1994; 120: 653-662.

175 Mustafa NA, Akturk G, Ozen I, Koksal I, Erciyes N, Solak M. Acute stress bleeding prophylaxis with sucralfate versus ranitidine and incidence of secondary pneumonia in intensive care unit patients. Intensive Care Med 1995; 21: 287.

176 Laggner AN, Lenz K, Base W, Druml W, Schneeweiss B, Grimm G. Prevention of upper gastrointestinal bleeding in long-term ventilated patients. Sucralfate versus ranitidine. Am J Med 1989; 86: 81-84.

177 Pickworth KK, Falcone RE, Hoogeboom JE, Santanello SA. Occurrence of nosocomial pneumonia in mechanically ventilated trauma patients: a comparison of sucralfate and ranitidine. Crit Care Med 1993; 21: 1856-1862.

178 Thomason MH, Payseur ES, Hakenewerth AM, et al. Nosocomial pneumonia in ventilated trauma patients during stress ulcer prophylaxis with sucralfate, antacid, and ranitidine. J Trauma 1996; 41: 503-508.

179 O'Keefe GE, Gentilello LM, Maier RV. Incidence of infectious complications associated with the use of histamine2-receptor antagonists in critically ill trauma patients. Ann Surg 1998; 227: 120-125.

180 Messori A, Trippoli S, Vaiani M, Gorini M, Corrado A. Bleeding and pneumonia in intensive care patients given ranitidine and sucralfate for prevention of stress ulcer: meta-analysis of randomised controlled trials. BMJ 2000; 321: 1103-1106.

181 Bornstain C, Azoulay E, De Lassence A, et al. Sedation, sucralfate, and antibiotic use are potential means for protection against early-onset ventilator-associated pneumonia. Clin Infect Dis 2004; 38: 1401-1408.

182 Phillips JO, Metzler MH, Palmieri MT, Huckfeldt RE, Dahl NG. A prospective study of simplified omeprazole suspension for the prophylaxis of stress-related mucosal damage. Crit Care Med 1996; 24: 1793-1800.

183 Lasky MR, Metzler MH, Phillips JO. A prospective study of omeprazole suspension to prevent clinically significant gastrointestinal bleeding from stress ulcers in mechanically ventilated trauma patients. J Trauma 1998; 44: 527-533.

184 Levy MJ, Seelig CB, Robinson NJ, Ranney JE. Comparison of omeprazole and ranitidine for stress ulcer prophylaxis. Dig Dis Sci 1997; 42: 1255-1259.

185 Yildizdas D, Yapicioglu H, Yilmaz HL. Occurrence of ventilator-associated pneumonia in mechanically ventilated pediatric intensive care patients during stress ulcer prophylaxis with sucralfate, ranitidine, and omeprazole. J Crit Care 2002; 17: 240-245.

186 Conrad SA, Gabrielli A, Margolis B, et al. Randomized, double-blind comparison of immediate-release omeprazole oral suspension versus intravenous cimetidine for the prevention of upper gastrointestinal bleeding in critically ill patients. Crit Care Med 2005; 33: 760-765.

187 Kress JP, Pohlman AS, O'Connor MF, Hall JB. Daily interruption of sedative infusions in critically ill patients undergoing mechanical ventilation. N Engl J Med 2000; 342: 1471-1477.

188 Sierra R, Benítez E, León C, Rello J. Prevention and diagnosis of ventilator-associated pneumonia: a survey on current practices in Southern Spanish ICUs. Chest 2005; 128: 1667-1673.

189 Rello J, Lorente C, Bodí M, Diaz E, Ricart M, Kollef MH. Why do physicians not follow evidence-based guidelines for preventing ventilator-associated pneumonia? A survey based on the opinions of an international panel of intensivists. Chest 2002; 122: 656-661.

190 Cook D, Ricard JD, Reeve B, et al. Ventilator circuit and secretion management strategies: a Franco-Canadian survey. Crit Care Med 2000; 28: 3547-3554.

191 Ricart M, Lorente C, Diaz E, Kollef MH, Rello J. Nursing adherence with evidence-based guidelines for preventing ventilator-associated pneumonia. Crit Care Med 2003; 31: 2693-2696. 
192 Berwick DM, Calkins DR, McCannon CJ, Hackbarth AD. The 100,000 Lives campaign: setting a goal and a deadline for improving health care quality. JAMA 2006; 295: 324-327.
193 Masterton R, Craven D, Rello J, et al. Hospital-acquired pneumonia guidelines in Europe: a review of their status and future development. J Antimicrob Chemother 2007; 60: 206-213. 